\title{
Induction of chemokines and cytokines before neutrophils and macrophage recruitment in different regions of rat liver after TAA administration
}

\author{
Ahmad Amanzada ${ }^{1}$, Federico Moriconi ${ }^{1}$, Tümen Mansuroglu², Silke Cameron, Giuliano Ramadori and \\ Ihtzaz A Malik
}

Single-dose thioacetamide (TAA) administration induces inflammation and acute liver damage. The mechanism of inflammatory cell recruitment in the liver is still unclear. The aim of this study was to examine the sequence and recruitment of inflammatory cells in different liver regions in relation to CXC- and CC-chemokine and cytokine expression during acute liver injury. Single-dose TAA was administered to rats intraperitoneally, and animals were killed at different time points thereafter. Serum and liver tissue were taken and frozen immediately. Tissue was used for immunostaining cryostat sections, RNA, and protein extraction. RT-PCR and western blotting were performed for RNA and protein analysis, respectively. An early increase $(3 \mathrm{~h})$ in CXCL8/IL-8 levels was measured followed by a marked release in MCP1/CCL2 (24 h) serum levels after TAA administration compared with controls. Similarly, an early increase in specific RNA of hepatic chemokines CXCL1/KC and CXCL8/LL-8 was found at $3 \mathrm{~h}$, followed by an upregulation of CXCL5/LIX (6h), CXCL2/MIP-2 $(12 \mathrm{~h})$, and MCP1/CCL2 gene expression at 24-48 h. Further, an induction of pro-inflammatory cytokines IFN- $\gamma$ and IL-1 $\beta$ followed by IL- 6 and TNF- $\alpha$ was observed with a maximum at $12 \mathrm{~h}$. The magnitude of increase in gene expression of TNF- $\alpha$ and MCP1/CCL2 was the highest among all cytokines and chemokines, respectively. By means of immunohistochemistry, an early (12-24 h) increase in the number of only neutrophil granulocytes (NGs) attached to and around portal vessel walls was observed, followed by increased numbers of mononuclear phagocytes ( $24-48 \mathrm{~h}$ ) along the sinusoids. Treatment of the human monocytic cell line U-937 with TNF- $\alpha$ increased the gene expression of CXCL1/KC, CXCL8/IL-8, and MCP1/ CCL2. Conversely, adding of infliximab (IFX) to the culture medium inhibited this upregulation significantly. In conclusion, single-dose TAA administration induces a sequence of events with a defined upregulation of gene expression of inflammatory chemokines and cytokines and a transient accumulation of NGs within the portal area and macrophages along the sinusoids throughout the liver. Periportal inflammation seems to precede hepatocellular damage.

Laboratory Investigation (2014) 94, 235-247; doi:10.1038/labinvest.2013.134; published online 25 November 2013

KEYWORDS: acute liver injury; chemokines; cytokines; inflammation; inflammatory cells

Inflammation is often used to describe a series of signs and symptoms after soft tissue or bone injury. This term was originally used to describe the four classic signs of the affected tissue's response to trauma: redness, swelling, heat, and pain. ${ }^{1}$ The inflammatory process can be initiated through a variety of mechanisms, which include the introduction of pathogens as well as challenges to the system through chemical, thermal, and mechanical stresses. Regardless of the inciting factors, the events accompanying inflammation are somewhat consistent. For research purposes, a reproducible injury model of tissue inflammation and repair is required; one of such models is the thioacetamide (TAA)-induced liver injury. ${ }^{2,3}$ Specifically, it serves as an accepted paradigm to aid the understanding of the body's generalized inflammatory process and thereby of a significant number of liver injuries.

TAA is a potent centrilobular hepatotoxic agent that undergoes a two-step bioactivation mediated by microsomal

Clinic for Gastroenterology and Endocrinology, University Medical Center Goettingen, Goettingen, Germany

Correspondence: Dr IA Malik, PhD, Clinic for Gastroenterology and Endocrinology, University Medical Center Goettingen, Robert-Koch-Str. 40, Goettingen37075, Germany.

E-mail: i.malik@med.uni-goettingen.de

${ }^{1}$ These authors contributed equally to this work.

${ }^{2}$ Current address: Division of Gastroenterology, Klinikum Region Hanover GmbH, Constantinstr. 40, 30177 Hanover.

Received 18 May 2013; revised 20 September 2013; accepted 16 October 2013 
CYP2E1 to thioacetamide sulfoxide (TASO) and further to the reactive metabolite thioacetamide-S, S-dioxide (TASO2). ${ }^{4}$ It can induce inducible nitric oxide synthase (iNOS) and nuclear factor $\kappa \mathrm{B}(\mathrm{NF}-\kappa \mathrm{B})$, resulting in the expression of proinflammatory molecules, leading to centrilobular necrosis. ${ }^{3}$

The process of acute inflammation in the liver is still unclear. Inflammatory cells can be found mainly in the periportal area, pericentral area, and in the sinusoids. Although the sequence of recruitment of inflammatory cells into wounds is a distinct process, the precise mechanisms of acute liver injury are not yet fully understood. The occurrence of microscopically observable liver damage might be the result of a multistep process rather than at its origin.

The cellular processes of inflammation are regulated by a series of specific cell signals, resulting in a cascade of events including white blood cell (WBC) recruitment and activation. Neutrophil granulocytes (NG) are the first subpopulation of WBCs to enter traumatized or stressed tissues. ${ }^{5}$ The traditional understanding has been that these cytokines were released only by injured or stressed tissue, resulting in the localization of NGs to these injured tissues. The role of NGs in liver injury remains controversial, although NGs contribute to liver damage by generating reactive oxygen species (ROS). ${ }^{6}$

Currently, researchers focused on the mechanisms for NG recruitment and the function of these NGs in otherwise healthy, uninjured tissue. Among the most important questions regarding NGs and inflammation is whether the localization of NGs after passing the endothelium facilitates healing or tissue destruction. An early intervention may prove to be the most beneficial strategy in minimizing tissue injury and in facilitating tissue repair and recovery of function. ${ }^{7,8}$

Chemokines are thought to be responsible for recruiting inflammatory cells. They are actively involved in inflammation, tissue repair, and development of fibrosis. ${ }^{9}$ The chemokine family is divided into four main groups based on their structure and chemotactic activity for specific leukocyte populations: $\mathrm{C}, \mathrm{CC}, \mathrm{CXC}$, and $\mathrm{CX}_{3} \mathrm{C}$.

The CXC (or $\alpha$ ) chemokines, such as CXCL8/Interleukin-8 (IL-8), CXCL9/MIG, CXCL10/IP-10, CXCL11/ITAC, and CXCL12/SDF1, have the potential to activate and attract NGs and T lymphocytes, ${ }^{10}$ whereas the CC (or $\beta$ ) chemokines, such as monocyte chemoattractant protein $1 \mathrm{MCP} 1 / \mathrm{CCL} 2$, macrophage inflammatory protein-2 MIP-1 $\alpha /$ CCL3, MIP-1 $\beta /$ CCL4, MIP-3 $\alpha / C C L 20$, and MIP-3//CCL19, are predominantly chemoattractants for multiple leukocyte subtypes, including monocytes, eosinophils, basophils, T lymphocytes, dendritic cells, natural killer cells, and, to a lesser extent, NGs. ${ }^{11} \mathrm{NG}$ recruitment is regulated by a complex array of signals, ${ }^{12}$ including activated complement and the CXC family chemokines CXCL8/IL-8/or CINC-1, CXCL2/MIP-2, cytokineinduced neutrophil chemoattractant (CXCL1/KC), and lipopolysaccharide-induced CXC chemokine (CXCL5/LIX). ${ }^{10,13}$

Further, a local expression of CXCL1/KC and of CXCL2/ MIP-2 is considered to be important for NG-dependent hepatic injury induced by ischemia and reperfusion in mice. ${ }^{14}$
This process is regulated at multiple levels, but it may also depend in part on the local production of chemoattractant cytokines (interferon (IFN) $-\gamma$, tumor necrosis factor (TNF) $\alpha$ and so on.) or chemokines that function to modulate the activity of cell-surface adhesion receptors as well as to direct migration of targeted cells into the tissue site. ${ }^{10}$

In our previous work, we have shown that single-dose $\gamma$-irradiation (a model for acute liver injury) of rat liver changes the expression of proteins including those involved in iron metabolism. ${ }^{15,16}$ In addition, upregulation of the genes of pro-inflammatory chemokines (CINC1/CXCL8/IL8, CXCL10/IP-10, CXCL11/ITAC, MCP1/CCL2, CXCL9/ MIG, MIP-1 $\alpha$,/CCL3, MIP-1ß/CCL4, MIP-3 $\alpha / C C L 20$, MIP$3 \beta /$ CCL19, and CXCL12/SDF1) in $\gamma$-irradiated rat liver damage was observed. ${ }^{17}$ However, while NG recruitment was observed around the wall of the portal artery, no increase in mononuclear phagocytes was observed. ${ }^{17}$

The aim of this work was to study the sequence of induction of chemokine and cytokine gene expression and of inflammatory cell recruitment into the different regions of rat liver tissue by means of immunohistology after single-dose administration of TAA as well as the time kinetic of tissue damage.

\section{MATERIALS AND METHODS \\ Animals}

Eight- to twelve-week-old male Sprague-Dawley rats of about $170-200$ g body weight were purchased from HarlanWinkelmann (Borchen, Germany). The rats were kept under standard conditions with $12 \mathrm{~h} \mathrm{light/dark} \mathrm{cycles} \mathrm{and} \mathrm{ad} \mathrm{libi-}$ tum access to fresh water and food pellets. We adhered to the university's policies and relevant guidelines for care and use of laboratory animals. The treatment of the rats was reviewed, approved, and overseen by the local ethics committee of the University of Goettingen and the public authority on animal welfare.

\section{Antibodies}

A rabbit polyclonal antibody directed against rat neutrophil elastase (NE) was purchased from Calbiochem (Merck, Germany), and a mouse monoclonal antibody directed against rat CD-11b/c came from BD Pharmingen (USA). A mouse anti-rat ED-1 and mouse anti-rat ED-2 monoclonal antibody was purchased from Serotec (Duesseldorf, Germany) and stained by the APAAP method. ${ }^{18} \mathrm{~A}$ goat polyclonal antibody directed against MCP1/CCL2 (R\&D, Germany) and anti-rat NE were stained with the peroxidase (POD) method, as previously described. ${ }^{19}$ Anti- $\alpha$-SMA, ED-1 and anti-CD-11b/c antibodies were used for double immunofluorescence staining as described before. ${ }^{20}$

\section{Induction of Acute-Phase Reaction by Single-Dose TAA Administration}

An acute-phase reaction was induced by single-dose intraperitoneal injection of $300 \mathrm{mg} / \mathrm{kg}$ TAA; control animals received saline injection. Animals were killed at 1, 3, 6, 12, 24, 
48,72 , and $96 \mathrm{~h}$ after TAA administration under anesthesia with $90 \mathrm{mg} / \mathrm{kg}$ ketamine and $7.5 \mathrm{mg} / \mathrm{kg}$ xylazine. Livers were excised and removed. Tissues were rinsed with physiological saline, frozen in liquid nitrogen and stored at $-80^{\circ} \mathrm{C}$ until use. ${ }^{21}$

\section{Measurement of MCP1/CCL2 and CXCL8/IL-8 and Liver Enzymes at Serum Level}

At the different time points ranging from 1 to $96 \mathrm{~h}$ after single-dose TAA administration, blood samples from the inferior cave vein were collected from control and treated rats and used for detection of MCP1/CCL2 and CXCL8/IL-8 in the serum of rats with ELISA kits from Biosource (Germany). The samples containing serum were removed 1, 3, 6, 12, 24 48,72 , and $96 \mathrm{~h}$ after treatment and were processed according to the suppliers' instructions. Further, alkaline phosphatase (AP) activity was detected using a standard p-nitrophenolphosphate photometric assay (Roche, Germany). Aspartate aminotransferase (AST) and alanine aminotransferase (ALT) activities were measured using analysis kits (DiaSys, Germany) as instructed. Lactate dehydrogenase (LDH) and glutamate dehydrogenase (GLDH) were also measured as instructed.

\section{RNA Isolation and Quantitative Real-Time RT-PCR}

Total RNA from the rat livers was isolated as previously described. ${ }^{22}$ For real-time PCR, reverse transcription of RNA samples was performed using the Superscript kit from Invitrogen (Groningen, Netherlands) and following the manufacturers' instructions. Real-time PCR analysis of cDNA was performed at $95-60{ }^{\circ} \mathrm{C}$ for 45 cycles in the Sequence Detection System of Abi Prism 7000 (Applied Biosystems, Darmstadt, Germany), using an SYBR Green Reaction Master Mix (ABI Prism). The primers are listed in
Table 1. All our primers were gene specifically synthesized by Invitrogen (Groningen, Netherlands). In every RNA sample, $\beta$-actin mRNA was measured as the housekeeping gene (ubiquitin $\mathrm{C}$ was also measured with very similar results). Values were then compared with those obtained using the control RNA obtained from each saline-treated animal series. The results were normalized to the housekeeping gene, and fold change expression was calculated using threshold cycle $(\mathrm{Ct})$ values. For calculation of the relative changes, gene expression before treatment (treated or control) was set at 1 .

\section{Western Blot Analysis and SDS-PAGE}

Protein extraction and western blot analysis were performed as previously described. ${ }^{23}$ The immunodetection studies were performed according to the ECL western blotting protocol of GE Healthcare (Germany).

\section{Tissue Sectioning and Immunohistology}

$5-\mu \mathrm{m}$ thick cryostat liver tissue sections were cut, air-dried and fixed with methanol $\left(-20^{\circ} \mathrm{C}, 10 \mathrm{~min}\right)$ and acetone, respectively $\left(-20^{\circ} \mathrm{C}, 10 \mathrm{~s}\right)$, and stored at $-20^{\circ} \mathrm{C}$. After inhibition of endogenous peroxidase by incubating the slides with phosphate-buffered saline (PBS)-containing glucose/ glucose oxidase/sodium azide, they were treated with FCS for $30 \mathrm{~min}$ to minimize nonspecific staining. The sections were incubated in a humidified chamber with the first antibody directed against NE, ED-1, ED-2, CD11b/c, and $\alpha$-SMA diluted in PBS for $1 \mathrm{~h}$ at room temperature. These procedures were performed as described previously. ${ }^{23}$

\section{Isolation and Culture Conditions of Promonocytic Cell Line U-937}

U-937 promonocytic cells were seeded at $2 \times 10^{5}$ cells $/ \mathrm{ml}$ in RPMI 1640 medium containing $10 \%(\mathrm{v} / \mathrm{v})$ heat-inactivated

Table 1 Primers used for quantitative real-time RT-PCR

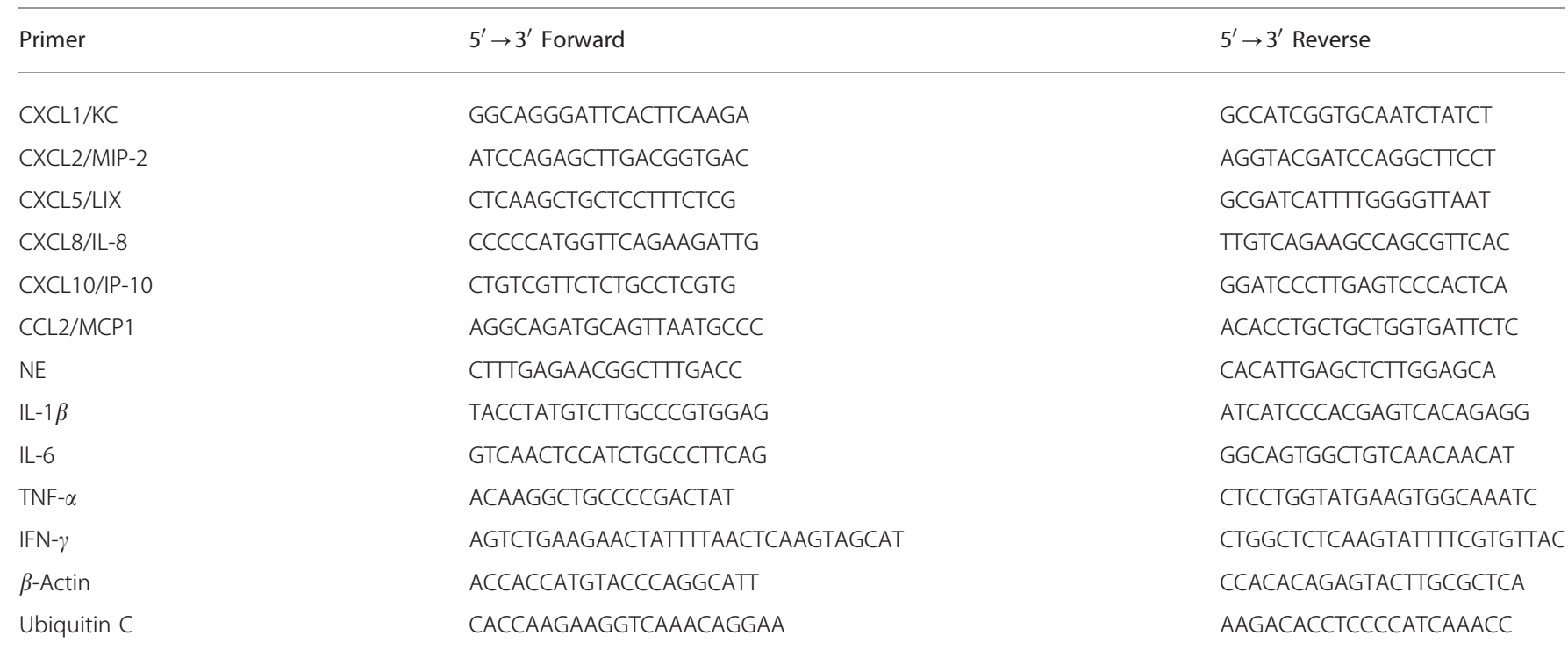



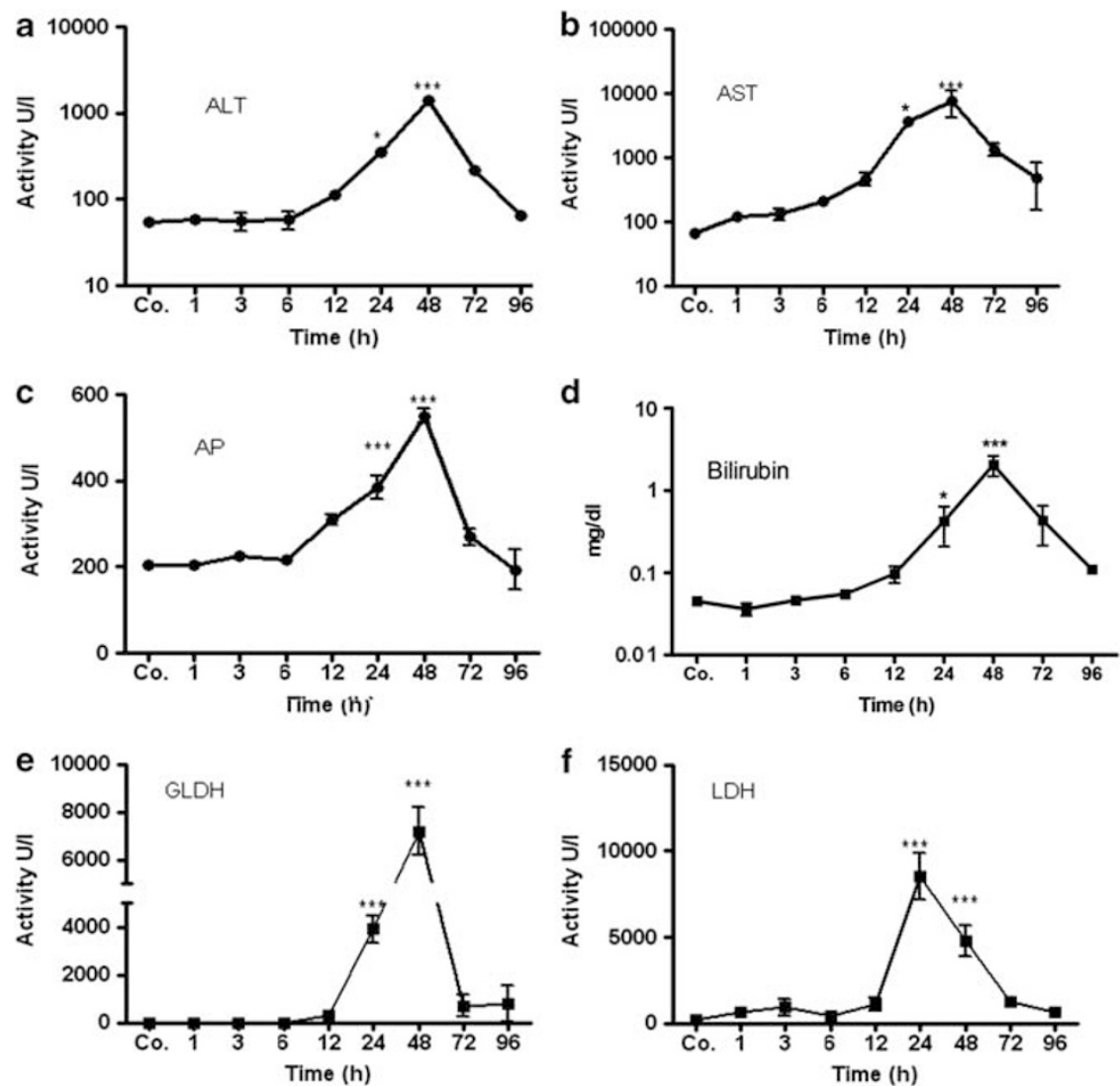

Figure 1 Serum enzyme and bilirubin levels in rats after single-dose TAA administration compared with controls. (a) Alanine aminotransferase (ALT); (b) aspartate aminotransferase (AST); (c) alkaline phosphatase (AP); (d) serum level of bilirubin; (e) glutamate dehydrogenase (GLDH); (f) lactate dehydrogenase (LDH). These results are representative of six animals (the increase at $48 \mathrm{~h}$ was found to be statistically significant for all studied enzymes by Student's $t$-test analysis and over the whole time course by one-way ANOVA, ${ }^{*} P<0.05, * * * P<0.001 ;$ mean \pm s.e.m.

fetal calf serum, $2 \mathrm{mM} / \mathrm{l}$ L-glutamine, $1 \mathrm{mM} / \mathrm{l}$ sodium pyruvate, and $1 \mathrm{mM}$ of non-essential amino acids and cultured at $37^{\circ} \mathrm{C}$ in an atmosphere of $95 \%$ air, $5 \% \mathrm{CO}_{2}$. In a second set of experiments, U-937 promonocytic cells were stimulated with either human TNF- $\alpha(10 \mathrm{ng} / \mathrm{ml})$ (Roche, Germany), IFX $(1000 \mu \mathrm{g} / \mathrm{ml})$ or TNF- $\alpha(10 \mathrm{ng} / \mathrm{ml})$ (Roche, Germany) in the presence of IFX.

\section{Statistical Analysis}

The data were analyzed using the Graph Pad Prism 4 software (San Diego, USA). All experimental errors are shown as s.e.m. Statistical significance was calculated by one-way ANOVA and Dunnett post hoc test. Significance was accepted at $P<0.05$.

\section{RESULTS}

\section{Kinetics of Changes of Liver Enzyme Serum Levels in Single-Dose TAA-Treated Rats}

In order to investigate liver damage, the serum levels of ALT, AST, AP, Bilirubin, GLDH, and LDH were analyzed after TAA administration. The serum activity of ALT, AST, AP, GLDH, and LDH as well as bilirubin was nearly constant until
$6 \mathrm{~h}$ after TAA administration (Figure 1). The serum activity of these enzymes and of the bilirubin level increased after 6-48 h significantly and decreased afterward until $96 \mathrm{~h}$. However, the level of these enzymes remained above that of control animals throughout the course of study (Figure 1). Similarly, LDH reached its peak after $24 \mathrm{~h}$ but decreased thereafter (Figure 1f).

\section{Kinetics of Changes of CXCL8/IL-8 and MCP1/CCL2 Serum Levels in Single-Dose TAA-Treated Rats}

We measured the serum levels of CXCL8/IL-8 and MCP1/ CCL2 after single-dose TAA administration. A significant $(P<0.05)$ early increase in serum CXCL8/IL-8 level at $3 \mathrm{~h}$ was detected. The maximum concentration (up to $3441 \pm 944 \mathrm{pg} / \mathrm{ml})(P<0.001)$ of CXCL8/IL-8 was found at $12 \mathrm{~h}$ followed by a quick decrease thereafter (Figure 2a). The serum levels of MCP1/CCL2 remained constant until $6 \mathrm{~h}$. It increased significantly at $12 \mathrm{~h}$ and reached a peak at $48 \mathrm{~h}$ $(91000 \pm 1000 \mathrm{ng} / \mathrm{ml})$ with a decrease thereafter. The MCP1/ CCL2 serum levels remained above control level even at $96 \mathrm{~h}$ after TAA administration (Figure $2 \mathrm{~b}$ ). 

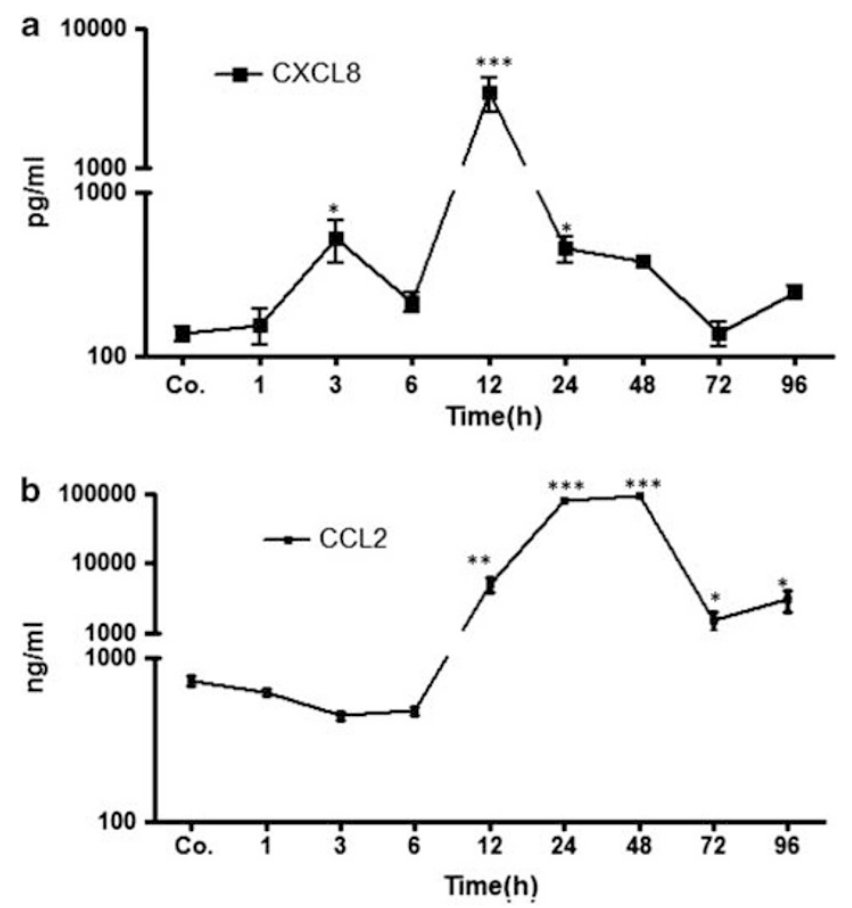

Figure 2 Serum chemokine levels after single-dose TAA administration compared with controls. (a) CXCL8/IL-8/-peptide levels in the serum of single-dose TAA-treated rats. (b) MCP1/CCL2-peptide serum levels of TAA-treated rats. Values on the $y$-axis show the serum concentration of CXCL8/IL-8 and MCP1/CCL2 measured with enzyme-linked immunosorbent assay. These results are representative of six animals (statistically significant at ${ }^{*} P<0.05,{ }^{*} P<0.01,{ }^{*}{ }^{*} P<0.001$; mean \pm s.e.m.).

\section{Kinetics of Changes of Pro-Inflmamtory Chemokine Gene Expression in Acute Rat Liver Damage Caused by Single-Dose TAA Administration}

In accordance with the serum level, by means of RT-PCR, the gene expression of CXCL8/IL-8 showed a significant early $(3 \mathrm{~h})$ increase, reaching a maximum $(154.9 \pm 43.8$ and $178 \pm 60.3$-fold, respectively) at $24 \mathrm{~h}$ after TAA treatment compared with control rat livers. Accordingly, an upregulation in the gene expression of CXCL1/KC was also measured. A gradual decrease in both chemokines was observed thereafter (Figures 3a and b). Similarly, CXCL2/MIP-2, CXCL5/ LIX, and CXCL10/IP-10 showed a significant increase at $12 \mathrm{~h}$ $(65 \pm 3, \quad 126 \pm 5$-fold and $194 \pm 64.8$-fold, respectively). CXCL5/LIX remained significantly upregulated until $96 \mathrm{~h}$ after TAA administration (Figure 3a). Similar to what was observed at serum level, MCP1/CCL2 gene expression was significantly increased at $12 \mathrm{~h}$ and peaked at $48 \mathrm{~h}$ $(983.9 \pm 254.8$-fold $)$ and remained significantly elevated until $96 \mathrm{~h}$ after TAA administration. The magnitude of MCP1/ CCL2 was highest among all studied chemokines (Figure 3c).

\section{Detection and Change in CXCL1/KC and CXCL8/IL-8 Protein Levels in Rat Liver after Single-Dose TAA Administration}

Similar to what we observed at RNA level, an increase in CXCL1/KC and CXCL8/IL-8 protein levels in the liver tissue
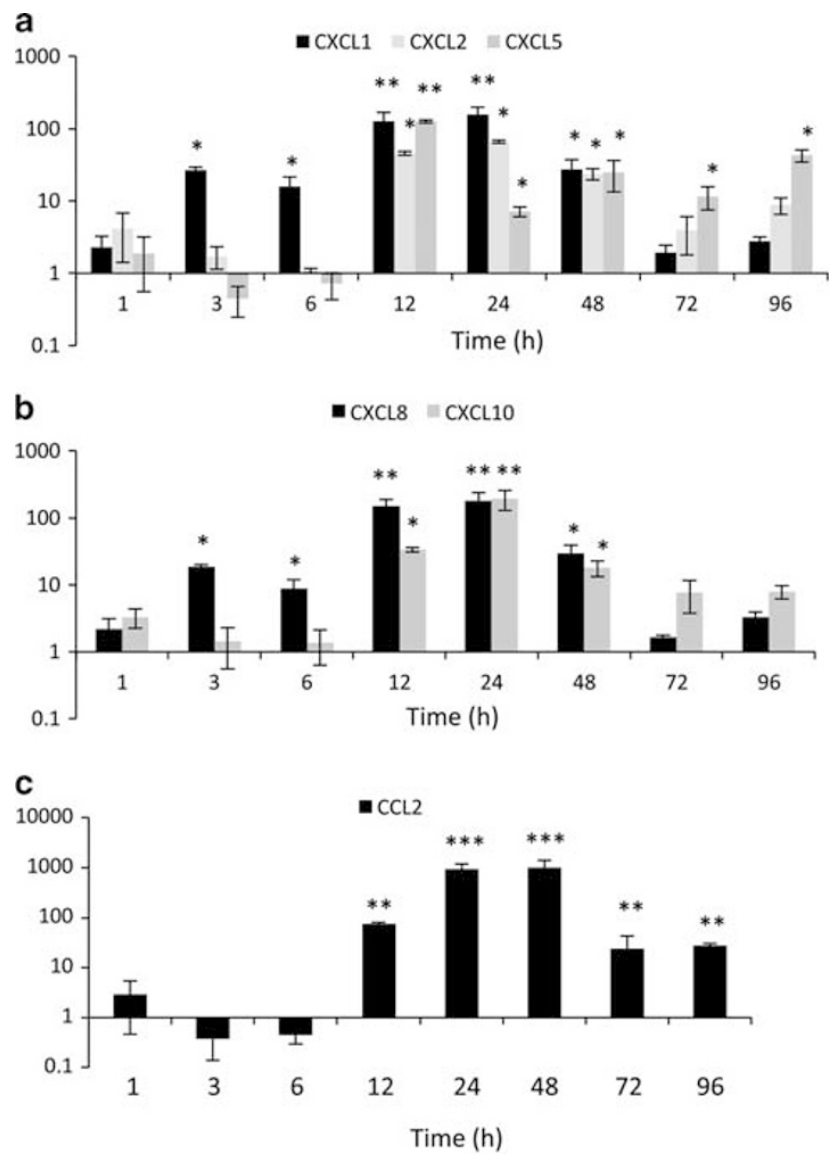

Figure 3 Fold change of mRNA expression of CXC-chemokines (CXCL1/ KC, CXCL2/MIP-2, CXCL5/LIX, CXCL8/IL-8, and CXCL10/IP-10) and of $\mathrm{MCP} 1 / \mathrm{CCL} 2$ in single-dose TAA-treated rat liver at different time points related to controls. (a, b) Maximum increase in CXCL1/KC, CXCL2/MIP-2, CXCL5/LIX, CXCL8/IL-8, and CXCL10/IP-10 gene expression is detectable at 12 and $24 \mathrm{~h}$ by RT-PCR. (c) MCP1/CCL2 gene expression was decreased at 3 and $6 \mathrm{~h}$ and reached its peak after 24 and $48 \mathrm{~h}$. RT-PCR was normalized to $\beta$-actin. Results represent mean \pm s.e.m. values of six experiments (in duplicate) compared with controls for each time point $\left({ }^{*} P<0.05,{ }^{* *} P<0.01,{ }^{* *} P<0.001\right.$ analyzed by one-way ANOVA).

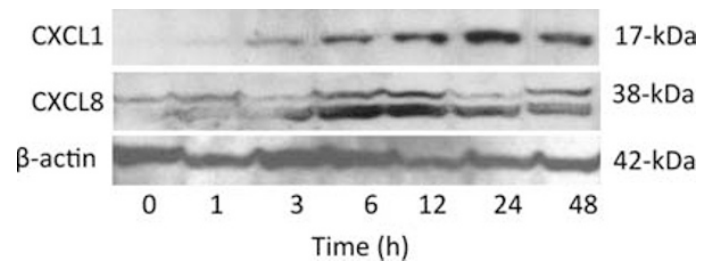

Figure 4 Detection of CXCL1/KC and CXCL8/LL-8 from total protein in rat liver at different time points after single-dose TAA administration by western blot. $\beta$-Actin was used as a marker for equal loading. Results are representative of six experiments.

lysate of TAA-treated rat was detected by immunoblotting. CXCL1/KC protein level started to increase at $1 \mathrm{~h}$ and remained above control level until $48 \mathrm{~h}$ in the liver. CXCL8/IL-8 protein level also started to increase early, with a maximum at $6-12 \mathrm{~h}$ after TAA administration and then decreased (Figure 4). 


\section{Kinetics of Changes in Pro-Inflammatory Cytokine Gene Expression in Rat Livers after Single-Dose TAA Administration}

By means of RT-PCR, gene expression of pro-inflammatory cytokines was measured in rat livers after TAA administration at different time points. The gene expression of IFN- $\gamma$

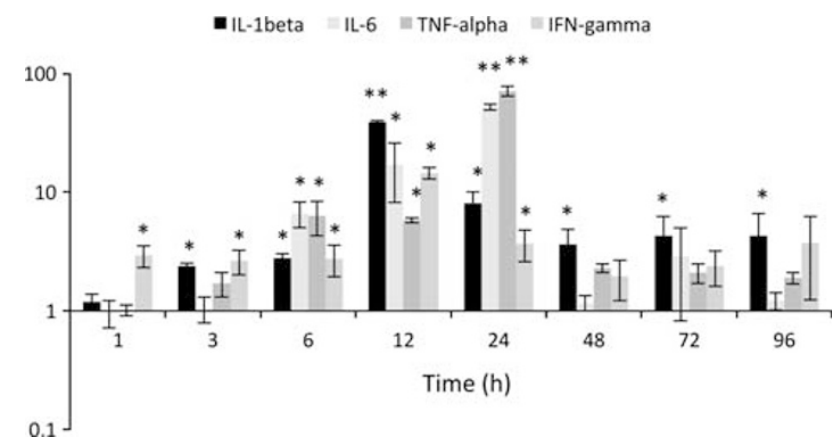

Figure 5 Fold change of mRNA expression of cytokines in single-dose TAA-treated rat liver. IL- $1 \beta$, IL-6, TNF- $\alpha$, and IFN- $\gamma$ gene expression reached its peak from 12 to $24 \mathrm{~h}$. RT-PCR was normalized to $\beta$-actin. Results represent mean \pm s.e.m. values of six experiments (in duplicate) compared with controls for each time point $\left({ }^{*} P<0.05,{ }^{* *} P<0.01\right.$ analyzed by one-way ANOVA). increased significantly at $1 \mathrm{~h}$ and that of IL- $1 \beta$ at $3 \mathrm{~h}$ after TAA administration, followed by IL- 6 and TNF- $\alpha$ at $6 \mathrm{~h}$. IL- $1 \beta$ and IFN $-\gamma$ showed the most pronounced increase ( $14 \pm 1.6$ and $40 \pm 1.2$-fold, respectively) at $12 \mathrm{~h}$ and IL-6 and TNF- $\alpha(53 \pm 1.7$ and $71 \pm 6$ fold, respectively) at $24 \mathrm{~h}$ after TAA administration, followed by a decrease thereafter. The increase was found to be highest for TNF- $\alpha$, followed by IL- 6 , IL- $1 \beta$, and IFN- $\gamma$ after TAA administration (Figure 5).

\section{Immunohistochemical Detection of NGs and Macrophages in TAA-Induced Injured Liver}

TAA administration can induce acute liver injury. After examination of serum enzyme activity and serum levels of chemokines, we performed immunohistochemical labeling of single-dose TAA-treated rat livers with antibodies against NE, ED-1, and ED-2. Figure 6 and Supplementary Figure 1 show an early increase in $\mathrm{NE}^{+}$cells at $3 \mathrm{~h}$ and reached a maximum at $12-24 \mathrm{~h}(60.2 \pm 16.8)$ (Figure 6) around the portal fields and bile ducts of the rat liver after TAA administration. Very few $\mathrm{NE}^{+}$cells were observed in the parenchyma and central area of both, TAA-administered and control livers. Accordingly, at the same time, a significant increase (7.2 \pm 2.3 -fold at $6 \mathrm{~h}$ ) in NE gene expression at RNA level was detected by

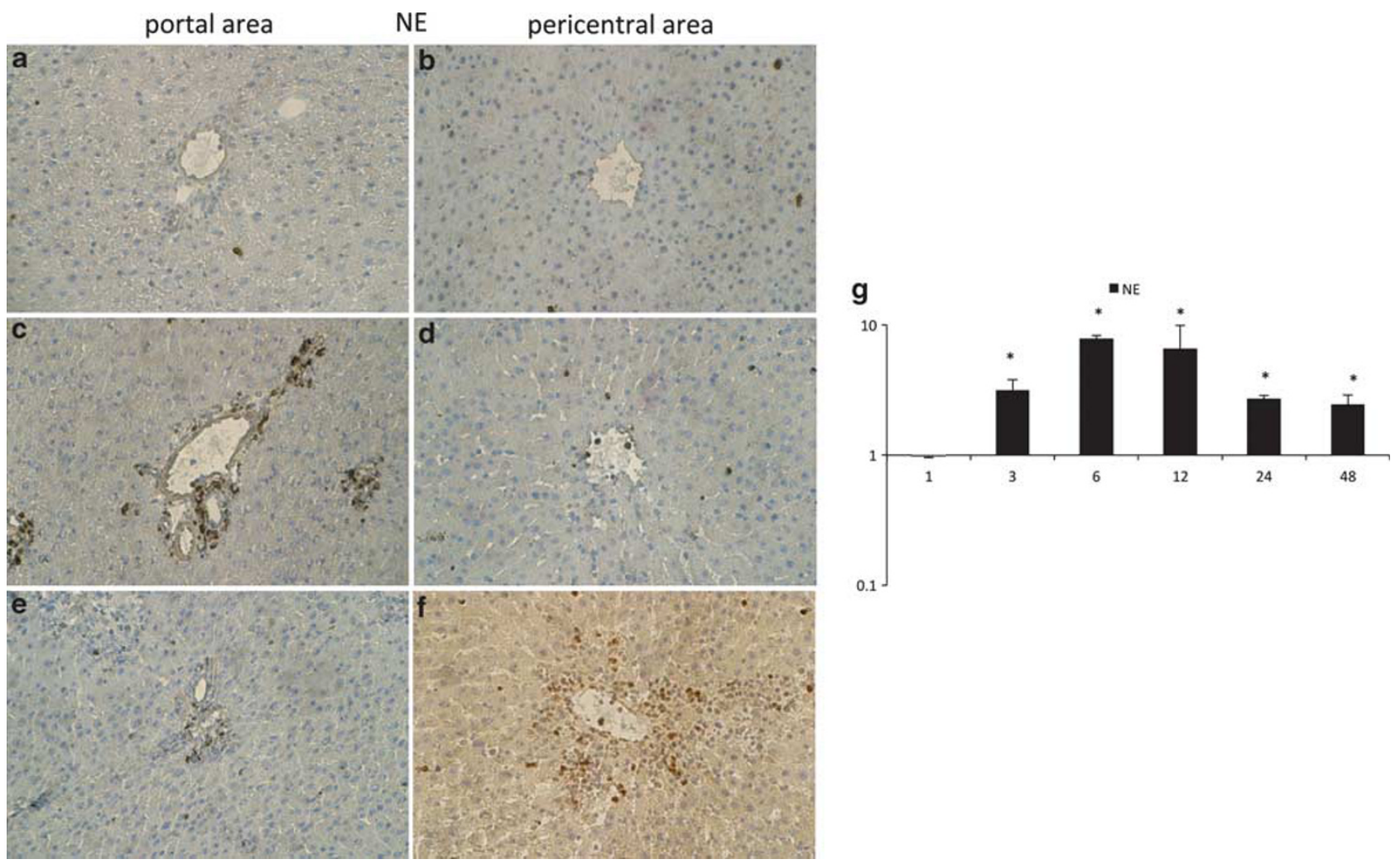

Figure 6 Immunodetection of neutrophil elastase (NE, a marker for neutrophil granulocytes) in sections of rat livers after single-dose TAA administration. Sections were stained with an antibody directed against NE followed by peroxidase staining (a-f). Panels $\mathbf{a}, \mathbf{b}$ show NE ${ }^{+}$cells (neutrophil granulocytes) at $0 \mathrm{~h}$. Panels $\mathbf{c}$ and $\mathbf{d}$ show $\mathrm{NE}^{+}$cells $12 \mathrm{~h}$ after treatment. Panels $\mathbf{e}$ and $\mathbf{f}$ show NE ${ }^{+}$cells after $48 \mathrm{~h}$. (g) Fold change in hepatic mRNA expression of NE as measured by RT-PCR at different time points. Upregulation of NE was detected after $3 \mathrm{~h}$ and reached its maximum at $6 \mathrm{~h}$. Results show representative pictures of six animals and six slides per time point. Results represent mean \pm s.e.m. values of six experiments (in duplicate) compared with controls for each time point $\left({ }^{*} P<0.05\right)$. Original magnification, $\times 200$. 


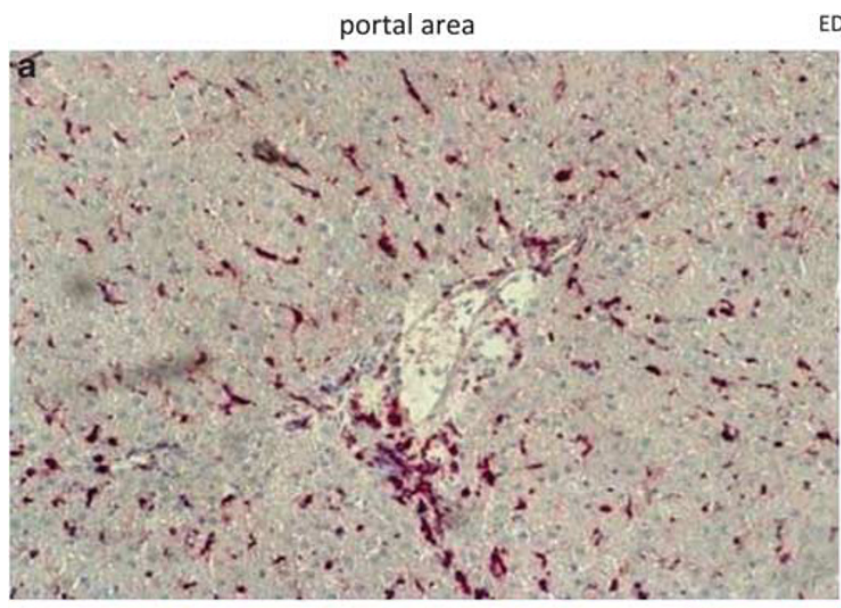

ED-1
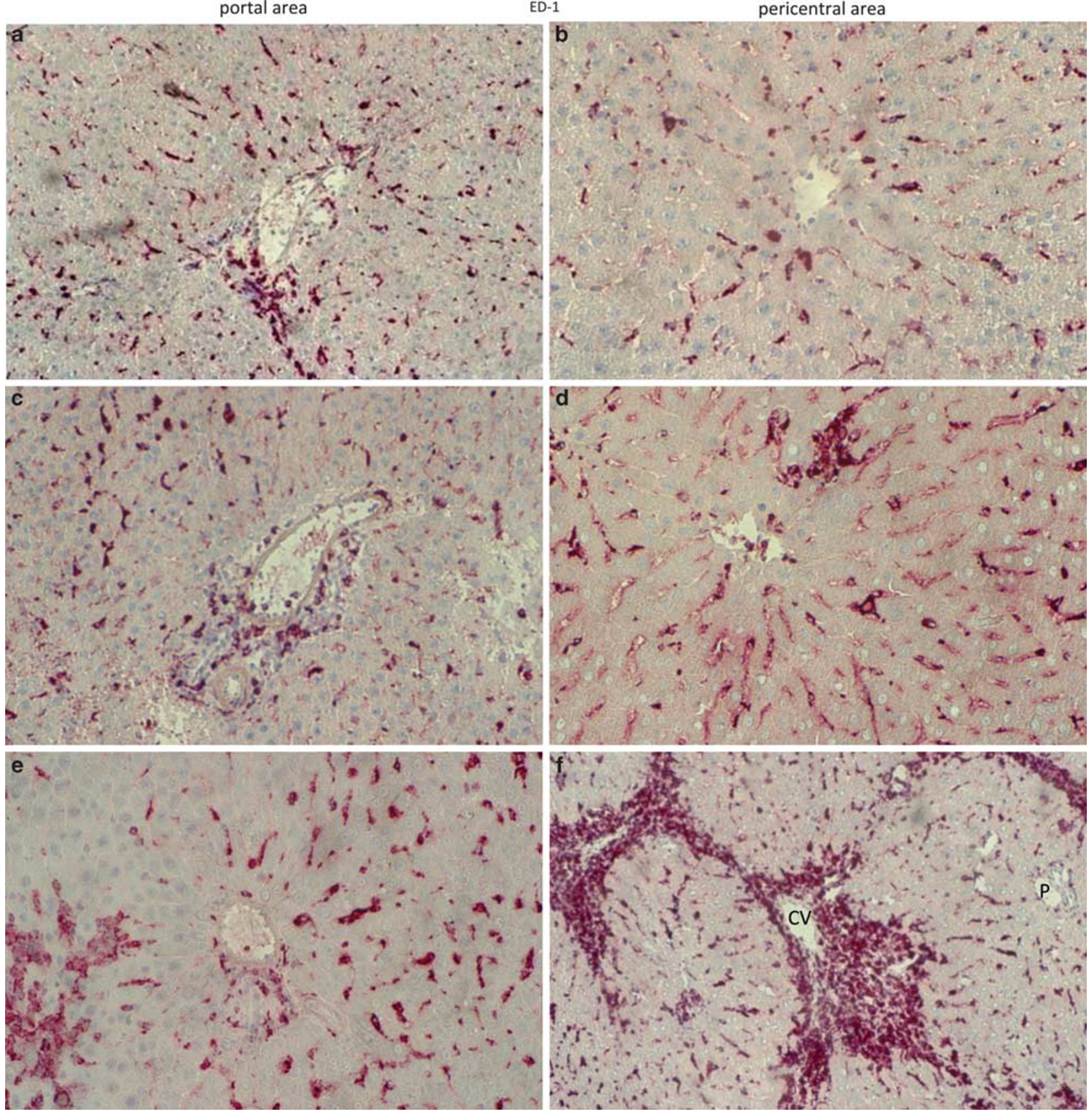

Figure 7 ED- ${ }^{+}$cells (recruited macrophages) in rat liver after single-dose TAA administration. Panels $\mathbf{a}$ and $\mathbf{b}$ show ED-1 ${ }^{+}$cells at $0 \mathrm{~h}$. Panels $\mathbf{c}$ and $\mathbf{d}$ show ED-1 ${ }^{+}$cells $12 \mathrm{~h}$ after treatment. Panels $\mathbf{e}$ and $\mathbf{f}$ show ED-1 ${ }^{+}$cells after $48 \mathrm{~h}$. The images are representative pictures of six animals and six slides per time point. (a-e) original magnification, $\times 200$, (f) original magnification, $\times 100$. CV, centrilobular vein; $P$, portal area.

RT-PCR analysis (Figure $6 \mathrm{~g}$ ). The number of $\mathrm{NE}^{+}$cells decreased after $48 \mathrm{~h}$. By using antibodies against macrophages ED-1 (Figure 7, Supplementary Figure 2) and ED-2 (Figure 8, Supplementary Figure 3), it was possible to detect an increase in $\mathrm{ED}-1^{+}$and ED-2 ${ }^{+}$cells after $12 \mathrm{~h}$. The increase in ED- $1^{+}$ and $\mathrm{ED}-2^{+}$cell numbers was mainly detected along the sinusoids, but some positivity around the portal fields was also detected at later time points $(48 \mathrm{~h})$. Further, after $24-48 \mathrm{~h}$ of
TAA administration, clear inflammatory septa indicating portal to central inflammation were observed.

\section{Identification of Recruited Inflammatory Cells by Immunofluorescence Double Staining in Acute Rat Liver damage Caused by Single-Dose TAA Administration}

By means of double immunofluorescence staining using antibodies against CD-11b/c and ED-1, an accumulation of 


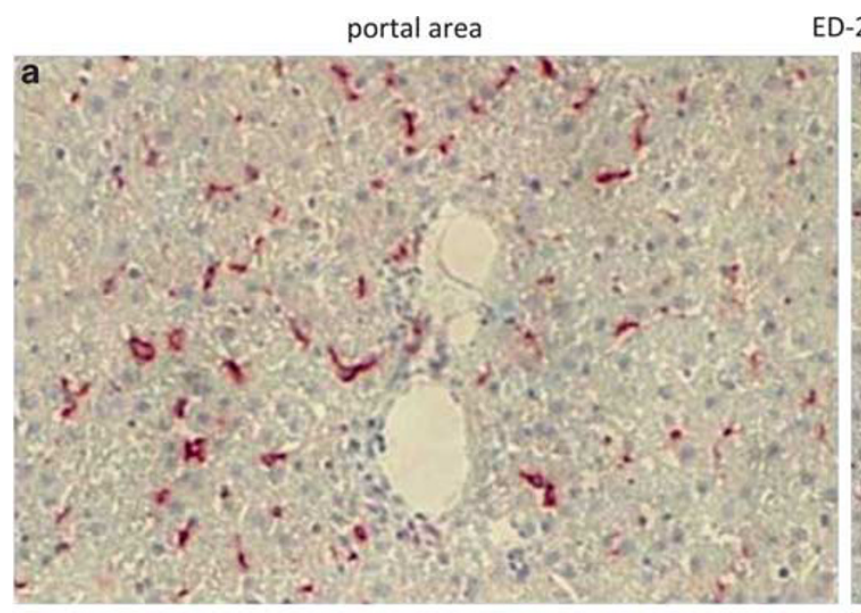

ED-2
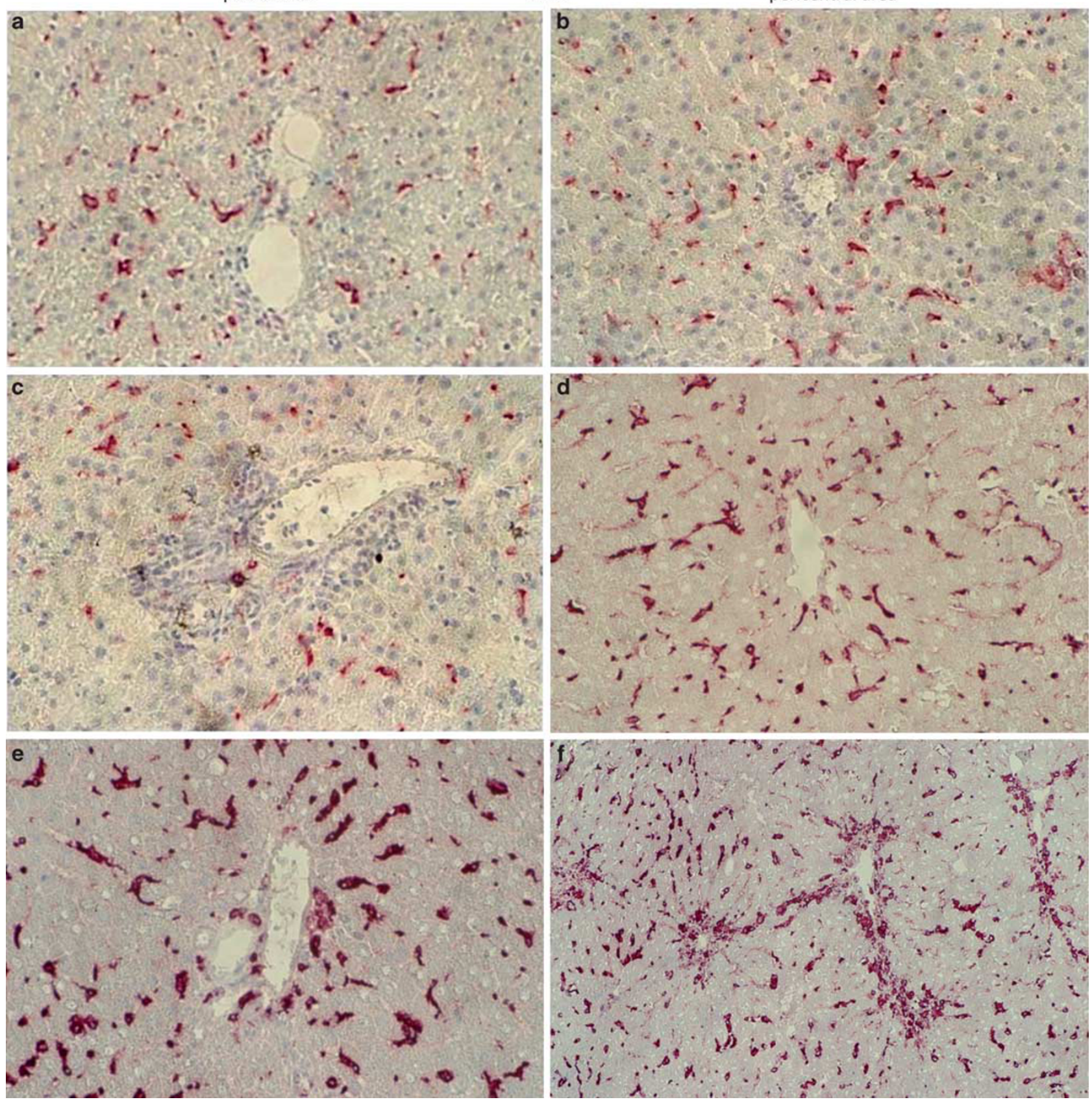

Figure $8 \mathrm{ED}-2^{+}$cells (resident macrophages) in rat liver after single-dose TAA administration. Panels a and $\mathbf{b}$ show ED-2 ${ }^{+}$cells at $0 \mathrm{~h}$. Panels $\mathbf{c}$ and $\mathbf{d}$ show ED-2 ${ }^{+}$cells $12 \mathrm{~h}$ after treatment. Panels $\mathbf{e}$ and $\mathbf{f}$ show ED-2 ${ }^{+}$cells after $48 \mathrm{~h}$. Results show representative pictures of six animals and six slides per time point. (a-e) original magnification, $\times 200$, (f) original magnification, $\times 100$.

$\mathrm{CD} 11 \mathrm{~b} / \mathrm{c}^{+}$cells (marker of both granulocytes and macrophages) was detected after $3 \mathrm{~h}$ with a maximum at $24 \mathrm{~h}$ mainly around portal vessels of rat liver after TAA administration (Figure 9 and Supplementary Figure 4). Using the antibody against ED-1, an accumulation of $\mathrm{ED}-1^{+}$cells could be detected at 12-24 h mainly around the central area but to a lesser extend around the portal vessels after TAA administration (Figure 9 and Supplementary Figure 4). The number of $\mathrm{CD}-11 \mathrm{~b} / \mathrm{c}^{+}$cells around the portal area decreased at later time points $(96 \mathrm{~h})$ (data not shown). The double immunostaining of CD-11b/c and ED-1 showed a co-expression of ED-1 ${ }^{+}$cells in the parenchyma (macrophages) and with CD-11b/c (Figure 9 and Supplementary Figure 4). Double immunofluorescence staining using antibodies against CD-11b/c and $\alpha$-SMA revealed few CD- $11 \mathrm{~b} / \mathrm{c}^{+}$cells around the $\alpha-\mathrm{SMA}^{+}(($myo $)$fibroblast marker) cells in vessels of the portal area after $12 \mathrm{~h}$ in rat liver. With an increase in liver damage, the number of $\mathrm{CD}-11 \mathrm{~b} / \mathrm{c}^{+}$cells increased 

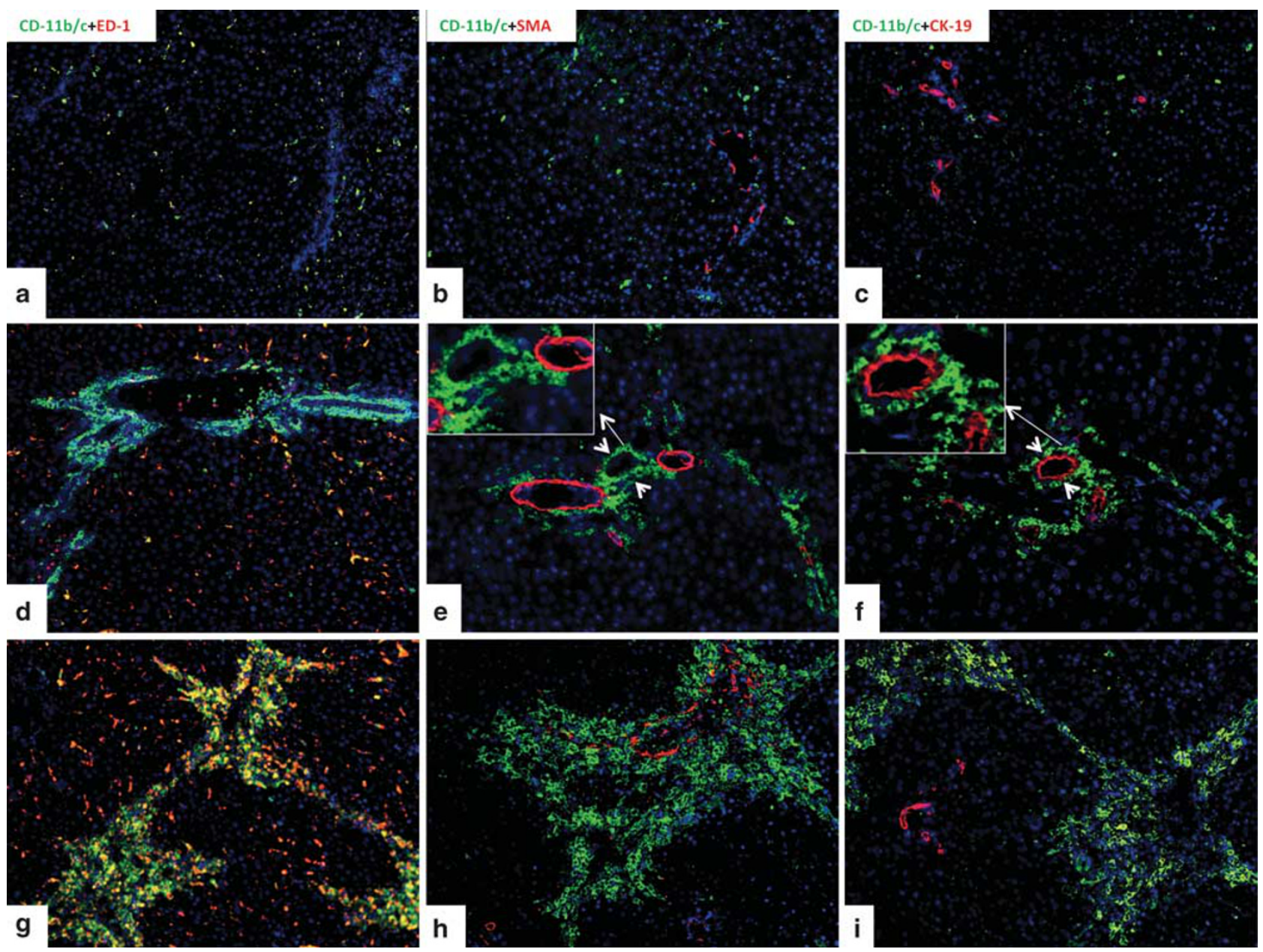

Figure 9 Double staining of liver sections with antibodies directed against CD-11b/c (green, a marker for granulocytes and macrophages), ED-1 (red, a marker for resident macrophages), $\alpha$-SMA (red, a marker for myofibroblasts), and CK-19 (red, a marker for cytokeratin 19) followed by fluorescence immunodetection in sections of rat liver after single-dose TAA administration (a-c) liver sections at $0 \mathrm{~h}$; (d-f) liver sections at $12 \mathrm{~h}$; $(\mathbf{g}$-i) liver sections at

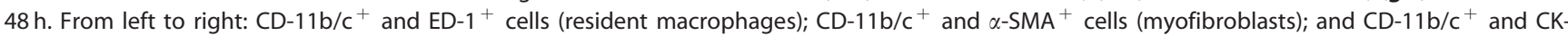
$19^{+}$cells (marker for bile duct cells). Results show representative pictures of six animals and six slides per time point. Original magnification, $\times 200$.

around the $\alpha$-SMA ${ }^{+}$cells after $24 \mathrm{~h}$ throughout the liver (Figures $9 \mathrm{~b}$, e and $\mathrm{h}$ ). Similarly, an increased number of $\mathrm{CD}-11 \mathrm{~b} / \mathrm{c}^{+}$cells was also observed around the CK-19+ cells (marker for bile duct cells), whereas the number of $\mathrm{CD}-11 \mathrm{~b} / \mathrm{c}^{+}$cells surrounded by biliary cells was much more than what was observed around the $\mathrm{SMA}^{+}$cells at $12 \mathrm{~h}$ in rat liver after TAA administration (Figures $9 \mathrm{c}, \mathrm{f}$ and i). The positivity of $\mathrm{CD}-11 \mathrm{~b} / \mathrm{c}^{+}$cells around the CK- $19^{+}$cells decreased with the onset of time.

\section{Immunohistochemical Detection of MCP1/CCL2 in Rat Livers after Single-Dose TAA Administration}

Using the antibody against MCP1/CCL2, an increased MCP1/CCL2 detection was visible in the portal area after 6 to $12 \mathrm{~h}$ with a further increase at $24-48 \mathrm{~h}$ (Figure 10) and a decrease thereafter. Apart from weak hepatocyte positivity at 6 to $12 \mathrm{~h}, \mathrm{MCP}^{+}{ }^{+} / \mathrm{CCL} 2^{+}$cells were found in the portal areas of the liver. At 24 to $48 \mathrm{~h}$, a progressive increase in MCP1/CCL2 was detected not only in stressed hepatocytes but also in small round cells $(48 \mathrm{~h})$ within the portal and central area of the liver after TAA administration (Figure 10).

\section{Modulation of Pro-Inflammatory Chemokines (CXCL1/ KC, CXCL8/IL-8, and MCP1/CCL2) Gene Expression, in Cultured Human Monocytic Cells U-937}

To investigate the role of TNF- $\alpha$ on chemokine gene regulation, human monocytic cells U-937 were treated with TNF- $\alpha$ in the presence and absence of anti-TNF- $\alpha$ (IFX). A significant early increase in CXCL1/KC and CXCL8/IL-8 mRNA was measured in human monocytic cells U-937 at $2-4 \mathrm{~h}$ after TNF- $\alpha$-administration as compared with the IFX- and nontreated control U-937 cells (Figures 11a and b). Similarly, a significant increase in MCP1/CCL2 gene expression was observed at $4 \mathrm{~h}$ after TNF- $\alpha$ administration 


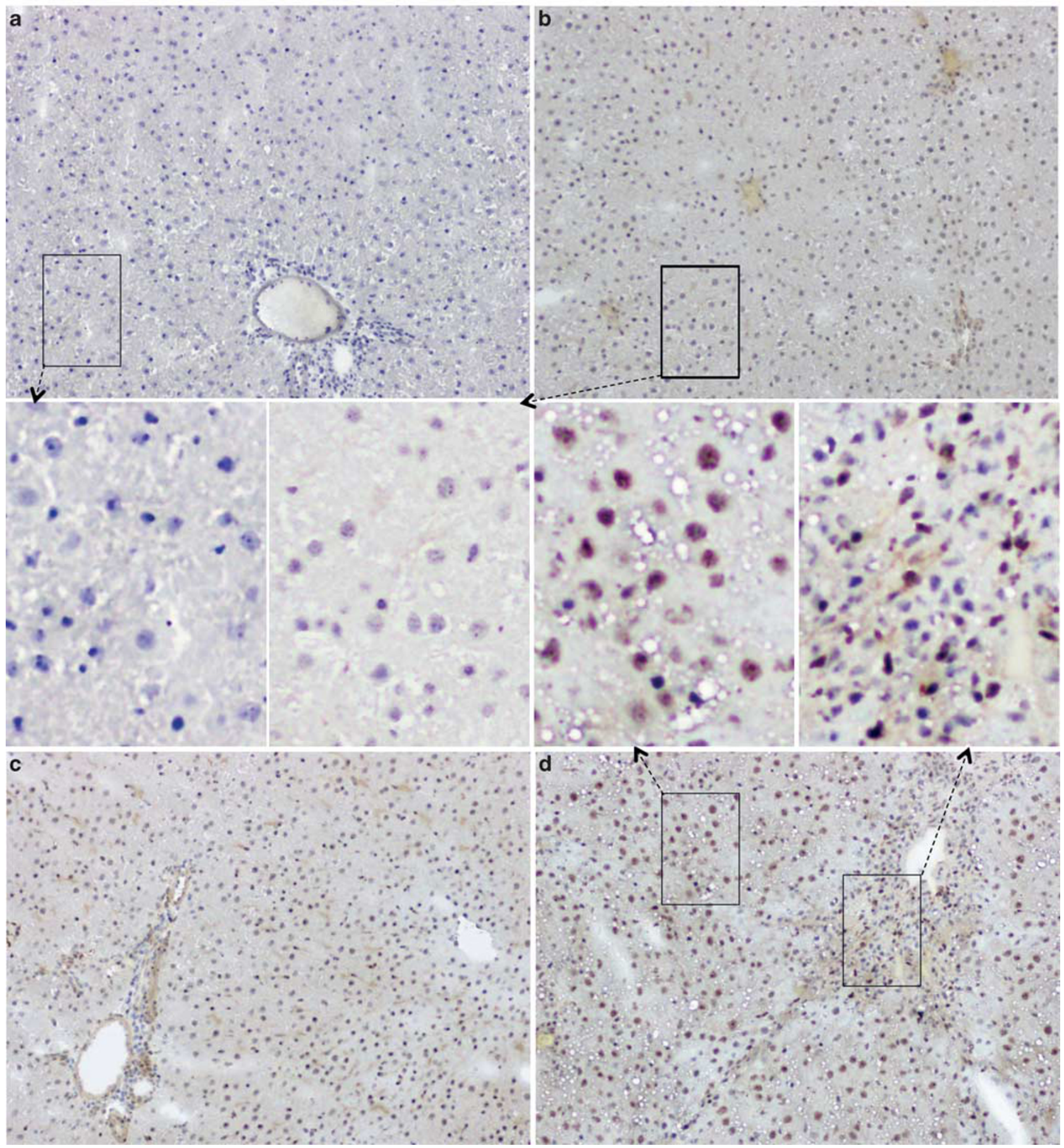

Figure 10 Immunodetection of MCP1/CCL2 in control (immunonegative serum, (a) rat liver sections and at $0 \mathrm{~h}$ (b), 12 (c) and $48 \mathrm{~h}$ (d) after single-dose TAA administration. Sections were stained with a goat polyclonal antibody directed against MCP1/CCL2 followed by peroxidase staining. (Original magnification, $\times 200$ ). Negative control (a) was performed by using only secondary antibody against goat immunoglobulin followed by peroxidase staining. Results represent mean value of six animals and six slides per time point.

(Figure 11c). The most pronounced increase was seen for CXCL8/IL-8 and MCP1/CCL2 gene expression at 2 and $4 \mathrm{~h}$ after the start of TNF- $\alpha$ administration. The upregulating effect of TNF- $\alpha$ administration was significantly decreased by addition of anti-TNF- $\alpha$ (IFX) to the culture medium.

\section{DISCUSSION}

The clinical features, biochemical and histological modifications in TAA-induced liver damage have been widely studied and are highly similar to those of human acute liver damage. ${ }^{24}$ Although acute drug-induced liver injury followed 

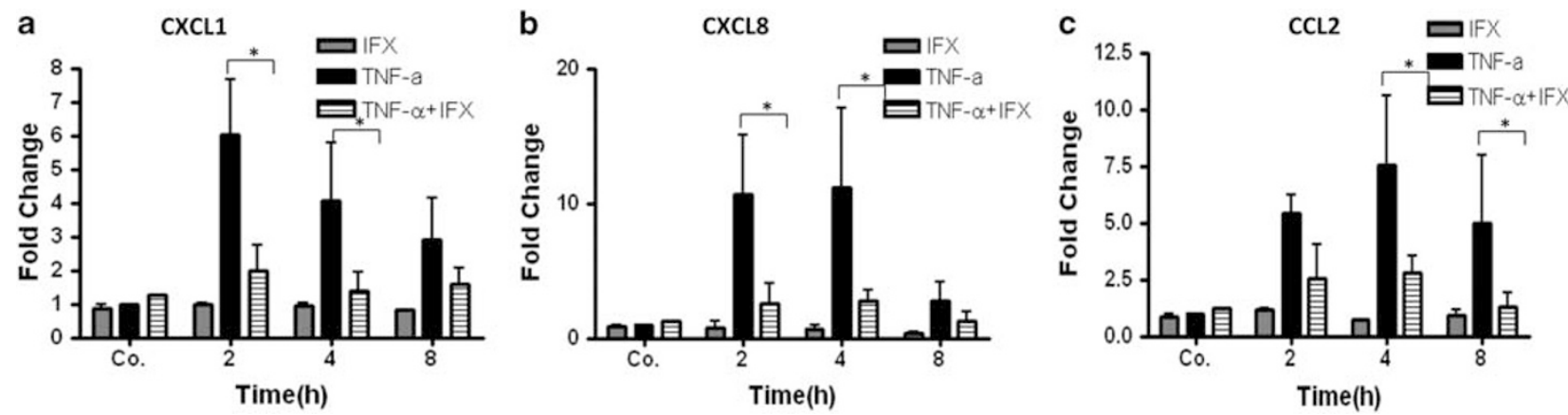

Figure 11 Fold change of mRNA expression of chemokines in the human U-937 cell line after treatment with infliximab (IFX), tumor necrosis factoralpha (TNF- $\alpha$ ) or both. CXCL1, CXCL8, and CCL2 gene expression significantly reached its peak at 2 or $4 \mathrm{~h}$ after TNF- $\alpha$ treatment. RT-PCR was normalized to $\beta$-actin. Results represent mean \pm s.e.m. values of six experiments (in duplicate) compared with controls for each time point $\left({ }^{*} P<0.05\right.$, analyzed by one-way ANOVA). Primers used for quantitative real-time RT-PCR.

by leukocyte infiltration is known, ${ }^{6}$ the sequence and recruitment of inflammatory cells into different regions of the liver during acute liver injury caused by single-dose TAA treatment has not been described. Moreover, the timedependent recruitment of inflammatory cells into the different regions of rat liver tissue in relation to proinflammatory mediators (eg, chemokines and cytokines) has also been poorly illustrated.

In our previous studies, a release of pro-inflammatory cytokines (first IFN- $\gamma$ and then TNF- $\alpha$ ) was observed followed by the recruitment and migration of mononuclear cells within the perisinusoidal space of the liver in a carbontetrachloride-induced acute injury rat model. ${ }^{25,26}$ In the present study, we administered a single dose of TAA intraperitoneally to induce reversible liver damage in rats. Liver damage was confirmed by elevated circulating serum levels of hepatic enzymes and massive upregulation of gene expression of acute-phase cytokines such as IFN- $\gamma$, TNF- $\alpha$, IL- $1 \beta$, and IL- 6 in TAA-treated rats. The circulating levels of liver enzymes (AST, ALT, AP, LDH, and GLDH) were found to be more pronounced at 24 and $48 \mathrm{~h}$ followed by a decrease to baseline levels at 72 and $96 \mathrm{~h}$, indicating acute liver damage followed by recovery.

After TAA administration, an early and brisk (3-12 h) serum and hepatic CXC-chemokine (CXCL8/IL-8) increase was measured at protein and RNA levels followed by infiltration of NGs only into the portal area, mainly between and around the liver biliary cells $\left(\mathrm{CK}-19^{+}\right)$and to some extent around the liver myofibroblasts (LMFs, $\mathrm{SMA}^{+}$cells) but neither along the sinusoids nor around the central vein.

Similarly, a late (12-48 h) but marked induction of serum and hepatic CC-chemokine (MCP1/CCL2) together with an increased number of mononuclear phagocytes (ED-1 ${ }^{+}$, ED $-2^{+}$) was observed mainly along the sinusoids by immunohistochemical analysis. Immunohistological analysis allowed to localize MCP1/CCL2 not only in hepatocytes and biliary cells but also in newly recruited cells. In fact, the role of these inflammatory cells in liver injury and their relation to inflammatory mediators (cytokines and chemokine) has not been fully explored. Chemokines represent a large family of chemotactic peptides with a broad range of cellular targets and can be produced by hepatocytes, sinusoidal endothelium, cholangiocytes, Kupffer cells, and stellate cells. ${ }^{9}$ Chemotactic signals include CXC chemokines such as CXCL1/KC, CXCL2/ MIP-2, CXCL5/LIX, and CXCL8/IL-8, which are potent chemoattractants for NGs and their increased production causes NG infiltration and extravasation. CC-chemokines such as MCP1/CCL2 are known to attract macrophages. ${ }^{9,27}$ The mechanism how MCP1/CCL2 attract leukocytes, mainly macrophages, is probably through the production of leukotriene $\mathrm{B}\left(\mathrm{LTB}_{4}\right)$ as shown in a murine model of septic peritonitis. ${ }^{28}$ In addition, another study reported that neutralization of MCP1/CCL2 activity in an LPS model of inflammation resulted in decreased monocyte accumulation, mainly within the intestinal muscularis. ${ }^{29}$ The results of our current study are in accordance with these reports. Taken together, recruitment of different inflammatory cell populations indicates a strong correlation with CXC- and CC-chemokines secreted by a variety of liver cells during acute hepatic injury.

Previous studies suggest that liver cells, including hepatocytes, can secrete chemokines under stress conditions, whereas Kupffer cells, biliary cells, and $\mathrm{LMFs}^{17,27}$ are considered to be the major cellular source of most of chemokines and cytokines, ${ }^{9,30}$ which are found in the portal area of the liver.

As most chemokines are localized in the portal area, ${ }^{17}$ this may explain why we see the early recruitment, that is, of NGs to the portal area. This implies that the initiation of liver inflammation may be initiated in the portal tract.

NGs do not attack healthy cells but respond to distressed or dying cells. ${ }^{6}$ In contrast, necrotic cells can also induce additional NG infiltration either by cell content release through complement activation and/or cytokine induction or by ROS generation.

In addition, macrophages (Kupffer cells) mediate induction of NG apoptosis as well as the ability to phagocytose apoptotic cells, which contributes to their role in the 
resolution of inflammation and promotion of tissue repair as has been reported for the acetyl-para-aminophenol-induced liver injury model. ${ }^{6}$ It could mean that NGs are followed by activation of Kupffer cells in order to eliminate toxin, tissue debris, and apoptotic bodies. This could also be true in our model as we observed the same sequence in the rat liver after TAA administration.

Recent studies show an increased expression of chemokines followed by cell recruitment after cytokine treatment in animal models, ${ }^{31,32}$ mainly through activated macrophages, which are known to generate pro-inflammatory cytokines and chemokines and several other mediators. ${ }^{17}$

Further, inhibition of these cytokines could reduce organ damage (inflammation) through lowering the cell infiltration numbers and downregulation of chemokine gene expression. ${ }^{33}$ To address the question of whether increase in proinflammatory chemokines during TAA-induced acute liver damage (current study) could also be due to the direct effect of inflammatory mediators (eg, TNF- $\alpha$ and IL-6), a human monocytic cell line U-937 (characteristics of macrophages) was cultured and treated with a 'major' pro-inflammatory cytokine (TNF- $\alpha$, the highest magnitude). Similar to what we observed in the liver tissue after TAA administration, an induction in gene expression of pro-inflammatory chemokines was found after a TNF- $\alpha$ treatment. This increase was inhibited signficantly by the addition of antiTNF- $\alpha$ to the culture medium of U-937 cells.

In conclusion, the present study could show that a single dose of TAA induces a fast and early increase in CXC-chemokines (CXCL1/KC, CXCL2/MIP-2, CXCL5/LIX, CXCL8/ IL-8) in the liver, accompanied by an increased number of NGs around the portal vessel walls between and around biliary cells and LMFs, but not in the parenchyma (sinusoids) as has been observed previously in our single-dose irradiation model of inflammation. ${ }^{17}$ In contrast, induction of CCchemokine (MCP1/CCL2) is followed by an increased number of macrophages spread throughout the liver. The induction of the mediators in cells of portal area (mainly LMFs and biliary cells) may happen through molecules such as ROS, which have been shown to be produced in the TAA model. ${ }^{34}$ Together with the data presented here, we suggest that upregulation of gene expression of several chemokines (mainly in LMFs and biliary cells) may be necessary to induce recruitment of inflammatory cells in a localized area beginning around the vessel walls within the portal area.

Supplementary Information accompanies the paper on the Laboratory Investigation website (http://www.laboratoryinvestigation.org)

\section{ACKNOWLEDGMENTS}

We greatly appreciate the helpful work of Mrs S Heyroth, A Herbst, and $\mathrm{R}$ Klages for their kind and skilful technical assistance. This study was partially supported by the research funding of University Medical Center, Goettingen, Germany.

\section{DISCLOSURE/CONFLICT OF INTEREST}

The authors declare no conflict of interest.

1. Rocha e Silva M. A brief survey of the history of inflammation. 1978. Agents Actions 1994;43:86-90.

2. Mansuroglu T, Ramadori P, Dudas J, et al. Expression of stem cell factor and its receptor c-Kit during the development of intrahepatic cholangiocarcinoma. Lab Invest 2009;89:562-574.

3. Shapiro $\mathrm{H}$, Ashkenazi $\mathrm{M}$, Weizman $\mathrm{N}$, et al. Curcumin ameliorates acute thioacetamide-induced hepatotoxicity. J Gastroenterol Hepatol 2006; 21:358-366.

4. Chilakapati J, Shankar K, Korrapati MC, et al. Saturation toxicokinetics of thioacetamide: role in initiation of liver injury. Drug Metab Dispos 2005;33:1877-1885.

5. Deng $B$, Wehling-Henricks $M$, Villalta SA, et al. IL-10 triggers changes in macrophage phenotype that promote muscle growth and regeneration. J Immunol 2012;189:3669-3680.

6. Jaeschke $H$, Hasegawa $T$. Role of neutrophils in acute inflammatory liver injury. Liver Int 2006;26:912-919.

7. Butterfield TA, Best TM, Merrick MA. The dual roles of neutrophils and macrophages in inflammation: a critical balance between tissue damage and repair. J Athl Train 2006;41:457-465.

8. Neubauer K, Lindhorst A, Tron K, et al. Decrease of PECAM-1-geneexpression induced by proinflammatory cytokines IFN-gamma and IFN-alpha is reversed by TGF-beta in sinusoidal endothelial cells and hepatic mononuclear phagocytes. BMC Physiol 2008;8:9.

9. Zimmermann HW, Tacke F. Modification of chemokine pathways and immune cell infiltration as a novel therapeutic approach in liver inflammation and fibrosis. Inflamm Allergy Drug Targets 2011;10: 509-536.

10. Van Sweringen HL, Sakai N, Tevar AD, et al. CXC chemokine signaling in the liver: impact on repair and regeneration. Hepatology 2011;54:1445-1453.

11. Berres ML, Nellen A, Wasmuth HE. Chemokines as immune mediators of liver diseases related to the metabolic syndrome. Dig Dis 2010;28: 192-196.

12. Frangogiannis NG, Smith CW, Entman ML. The inflammatory response in myocardial infarction. Cardiovasc Res 2002;53:31-47.

13. Chandrasekar B, Smith JB, Freeman GL. Ischemia-reperfusion of rat myocardium activates nuclear factor-KappaB and induces neutrophil infiltration via lipopolysaccharide-induced CXC chemokine. Circulation 2001;103:2296-2302.

14. van Golen RF, van Gulik TM, Heger M. The sterile immune response during hepatic ischemia/reperfusion. Cytokine Growth Factor Rev 2012;23:69-84.

15. Christiansen H, Batusic D, Saile B, et al. Identification of genes responsive to gamma radiation in rat hepatocytes and rat liver by cDNA array gene expression analysis. Radiat Res 2006;165:318-325.

16. Christiansen $\mathrm{H}$, Sheikh $\mathrm{N}$, Saile $\mathrm{B}$, et al. x-Irradiation in rat liver: consequent upregulation of hepcidin and downregulation of hemojuvelin and ferroportin-1 gene expression. Radiology 2007;242: 189-197.

17. Malik IA, Moriconi F, Sheikh N, et al. Single-dose gamma-irradiation induces up-regulation of chemokine gene expression and recruitment of granulocytes into the portal area but not into other regions of rat hepatic tissue. Am J Pathol 2010;176:1801-1815.

18. Moriconi F, Malik IA, Amanzada A, et al. The anti-TNF-alpha antibody infliximab indirectly regulates PECAM-1 gene expression in two models of in vitro blood cell activation. Lab Invest 2012;92: 166-177.

19. Sheikh N, Tron K, Dudas J, et al. Cytokine-induced neutrophil chemoattractant- 1 is released by the noninjured liver in a rat acutephase model. Lab Invest 2006;86:800-814.

20. Dudas J, Mansuroglu T, Batusic D, et al. Thy-1 is an in vivo and in vitro marker of liver myofibroblasts. Cell Tissue Res 2007;329:503-514.

21. Tron K, Novosyadlyy R, Dudas $J$, et al. Upregulation of heme oxygenase-1 gene by turpentine oil-induced localized inflammation: involvement of interleukin-6. Lab Invest 2005;85:376-387.

22. Ramadori G, Sipe JD, Dinarello CA, et al. Pretranslational modulation of acute phase hepatic protein synthesis by murine recombinant interleukin 1 (IL-1) and purified human IL-1. J Exp Med 1985;162: 930-942. 
23. Amanzada A, Malik IA, Nischwitz $M$, et al. Myeloperoxidase and elastase are only expressed by neutrophils in normal and in inflamed liver. Histochem Cell Biol 2011;135:305-315.

24. Rahman TM, Hodgson HJ. The effects of early and late administration of inhibitors of inducible nitric oxide synthase in a thioacetamideinduced model of acute hepatic failure in the rat. J Hepatol 2003; 38:583-590.

25. Knittel T, Dinter C, Kobold D, et al. Expression and regulation of cell adhesion molecules by hepatic stellate cells (HSC) of rat liver: involvement of HSC in recruitment of inflammatory cells during hepatic tissue repair. Am J Pathol 1999;154:153-167.

26. Neubauer K, Eichhorst ST, Wilfling T, et al. Sinusoidal intercellular adhesion molecule-1 up-regulation precedes the accumulation of leukocyte function antigen-1-positive cells and tissue necrosis in a model of carbontetrachloride-induced acute rat liver injury. Lab Invest 1998;78:185-194.

27. Kruglov EA, Nathanson RA, Nguyen T, et al. Secretion of MCP-1/CCL2 by bile duct epithelia induces myofibroblastic transdifferentiation of portal fibroblasts. Am J Physiol Gastrointest Liver Physiol 2006;290: G765-G771.

28. Matsukawa A, Hogaboam CM, Lukacs NW, et al. Endogenous monocyte chemoattractant protein-1 (MCP-1) protects mice in a model of acute septic peritonitis: cross-talk between MCP-1 and leukotriene B4. J Immunol 1999;163:6148-6154.

29. Turler A, Schwarz NT, Turler E, et al. MCP-1 causes leukocyte recruitment and subsequently endotoxemic ileus in rat. Am J Physiol Gastrointest Liver Physiol 2002;282:G145-G155.

30. Sprenger H, Kaufmann A, Garn H, et al. Induction of neutrophilattracting chemokines in transforming rat hepatic stellate cells. Gastroenterology 1997;113:277-285.

31. Krohn N, Kapoor S, Enami Y, et al. Hepatocyte transplantation-induced liver inflammation is driven by cytokines-chemokines associated with neutrophils and Kupffer cells. Gastroenterology 2009;136: 1806-1817.

32. Kawaratani H, Tsujimoto $\mathrm{T}$, Kitazawa $\mathrm{T}$, et al. Therapeutic effects of cytokine modulator Y-40138 in the rat alcoholic liver disease model. J Gastroenterol Hepatol 2011;26:775-783.

33. Saile $B$, Matthes $N$, Knittel $\mathrm{T}$, et al. Transforming growth factor beta and tumor necrosis factor alpha inhibit both apoptosis and proliferation of activated rat hepatic stellate cells. Hepatology 1999;30:196-202.

34. Chen TM, Subeq YM, Lee RP, et al. Single dose intravenous thioacetamide administration as a model of acute liver damage in rats. Int J Exp Pathol 2008;89:223-231. 